Chapter 6

\title{
Human Testis-Derived Pluripotent Cells and Induced Pluripotent Stem Cells
}

\author{
Hideyuki Kobayashi, Koichi Nagao and \\ Koichi Nakajima \\ Additional information is available at the end of the chapter \\ http://dx.doi.org/10.5772/55570
}

\section{Introduction}

Pregnancy rates achieved by intercourse in normal human couples are $20-25 \%$ per month, $75 \%$ by six months, and $90 \%$ by one year [1]. However, $15 \%$ of couples of unknown fertility status are unable to conceive a baby after one year of intercourse without contraception. For $30 \%$ of these couples, their infertility can be attributed to a male factor alone; in an additional $20 \%$, failure to conceive is explained by the presence of both male and female factors [2,3,4]. Among couples known to be infertile, a male factor is involved in $50 \%$ of the cases. The most common causes of male infertility include abnormal sperm production or function, impaired delivery of sperm, and overexposure to certain gonadotoxins in the environment. The pathogenesis of male infertility can be attributed to a disorder of germ-cell proliferation and differentiation or to somatic cell dysfunction [5].

The induction of spermatogenesis depends on the complementary actions of FSH and testosterone. FSH establishes the requisite Sertoli cell population. In the prepubertal primate, FSH alone can induce proliferation of Sertoli cells and spermatogonia, but this does not result in qualitatively and quantitatively normal spermatogenesis unless testosterone is simultaneously present [6] [7]. Testosterone affects the functional completion of meiosis and post-meiotic sperm differentiation and maturation. LH stimulates Leydig cells to produce testosterone. Although FSH appears to play a more dominant role in the maintenance of primate spermatogenesis than in its initiation, normal spermatogenesis is best maintained by the combined effects of FSH and LH [6].

The most severe form of male infertility is nonobstructive azoospermia, which is typically characterized by small-volume testes and elevated FSH. Patients with this disorder cannot 
produce biological children. Although microdissection testicular sperm extraction (microTESE) is used to treat patients with nonobstructive azoospermia [8], this technique does not have a good success rate. Therefore, new approaches are needed to develop treatments for male infertility.

Stem cells have the potential to differentiate into a variety of functional cell types in the body, and their discovery has given rise to the fields of regenerative medicine and cloning. Stem cells are regulated by the particular microenvironment in which they reside; these microenvironments are referred to as niches. Male germline stem cells can continuously produce sperm throughout adulthood, and investigators have sought to develop methods using stem cells to improve or restore fertility.

Embryonic stem cells (ESCs) have the potential to differentiate into nearly every cell type in the body. As the cells differentiate, they lose the ability to develop into different tissues. In contrast, specific tissues (gastrointestinal, integumentary, spermatogenic, and hematopoietic systems) maintain their regenerative capacity in vivo, and in fact, stem cells have been functionally identified in a wide range of adult tissues. These adult stem cells are believed to hold great promise for tissue generation in clinical settings. Here, we provide a summary of the therapeutic potential of stem cells for the rejuvenation of fertility in infertile males. Our hope is that future research will provide a range of options for the preservation of male fertility or the reversal of infertility.

\section{Differentiation and characterization of human primordial germ cells}

Human primordial germ cells (PGCs) can be isolated from tissues and their identity confirmed by observing their migratory activity in vitro [9]. Cultured human PGCs become human embryonic germ cells (hEGCs) in vitro, in the presence of feeder cells, leukemia inhibitory factor (LIF), and basic fibroblast growth factor (bFGF) [10]. hEGCs express alkaline phosphatase (AP), OCT4, SOX2, NANOG, stage specific embryonic antigen (SSEA)-3, SSEA-4, TRA-1-60, and TRA-1-81, which are pluripotent stem cell markers. In vivo, human PGCs do not express FGF4, SOX2 [11] [12], TRA-1-60, or TRA-1-81 [13] [14], which are expressed by hESCs or hEGCs in vitro. The molecular signature of human PGCs in vivo can be characterized as C-KIT+', SOX2-, TRA1-60-, TRA1-81', and FGF4-, in contrast with human pluripotent stem cell lines in vitro. (This information is summarized in Table 1.) However, the full complement of genes that are expressed specifically in human PGCs and their functions remain unclear.

\section{Spermatogonial stem cells}

Spermatogenesis is a complex and tightly regulated process in which a small pool of germline stem cells ultimately gives rise to spermatozoa [15]. These stem cells, called spermatogonial stem cells (SSCs) are found in the basal compartment of the seminiferous epithelium, where they adhere to the basement membrane. SSC self-renewal ensures the maintenance of 


\begin{tabular}{|l|c|c|c|c|}
\hline & hESChiPSC & hEGC & PGCs (early) & PGCs (late) \\
\hline OCT4 & + & + & + & + \\
\hline NANOG & + & + & + & $+/$ \\
\hline SOX2 & + & + & - & $?$ \\
\hline SSEA1 & - & + & + & + \\
\hline SSEA3 & + & + & $?$ & $?$ \\
\hline SSEA4 & + & + & + & + \\
\hline TRA1-60 & + & + & - & $?$ \\
\hline TRA1-81 & + & + & - & $?$ \\
\hline VASA & - & $?$ & - & + \\
\hline C-KIT & - & $?$ & + & + \\
\hline
\end{tabular}

Table 1. Markers of human pluripotent stem cells and germ cells.

the stem cell pool, while their differentiation generates a large number of germ cells. Therefore, a balance between SSC self-renewal and differentiation in the adult testis is essential to maintain normal spermatogenesis and fertility throughout life. SSCs need to reside in a unique environment, or niche, that provides the factors necessary for their survival and potency. In mice, Sertoli cells in the testis are a crucial component of the spermatogonial stem cell niche. They produce glial cell line-derived neurotrophic factor (GDNF), a distant member of the TGF $\beta$ family, which controls SSC self-renewal [16]. Several groups have reported that adding GDNF to freshly isolated germ cells in culture results in the proliferation of SSCs $[17,18]$. Other factors within the niche influence the fate of SSCs. One example is colony-stimulating factor 1 (CSF1), which is produced by Leydig cells and some peritubular myoid cells [19], and plays a role in SSC self-renewal (Figure 1).

The existence of SSCs was postulated almost 40 years ago on the basis of morphological studies [20] [21] [22] and observations of toxin-induced spermatogenic damage. The early studies of Clermont [23] [24] on human spermatogenesis revealed two types of spermatogonia, the $A_{\text {dark }}$ and $A_{\text {pale }}$ spermatogonia, which were differentiated by the staining pattern of their nucleus. Both cell types are generally considered stem cells [24,25]. $A_{\text {dark }}$ spermatogonia function as reverse stem cells that rarely divide, but can be triggered to self-renew in the case of injury or disease, while $A_{\text {pale }}$ spermatogonia are self-renewing stem cells $[23,24,25,26]$; they also divide into B spermatogonia, which further divide into spermatocytes [24].

In the last decade, molecular markers that can be used to identify and characterize human SSCs have been sought. A recent study reported that the expression of surface marker G protein coupled receptor 125 (GPR125) can be used in the isolation, characterization, and culture of putative human SSCs [27]. GPR125-positive spermatogonia are very rare, possibly limited to $A_{\text {dark }}$ spermatogonia or a sub-population of $A_{\text {pale }}$ spermatogonia. Human SSCs are also positive 


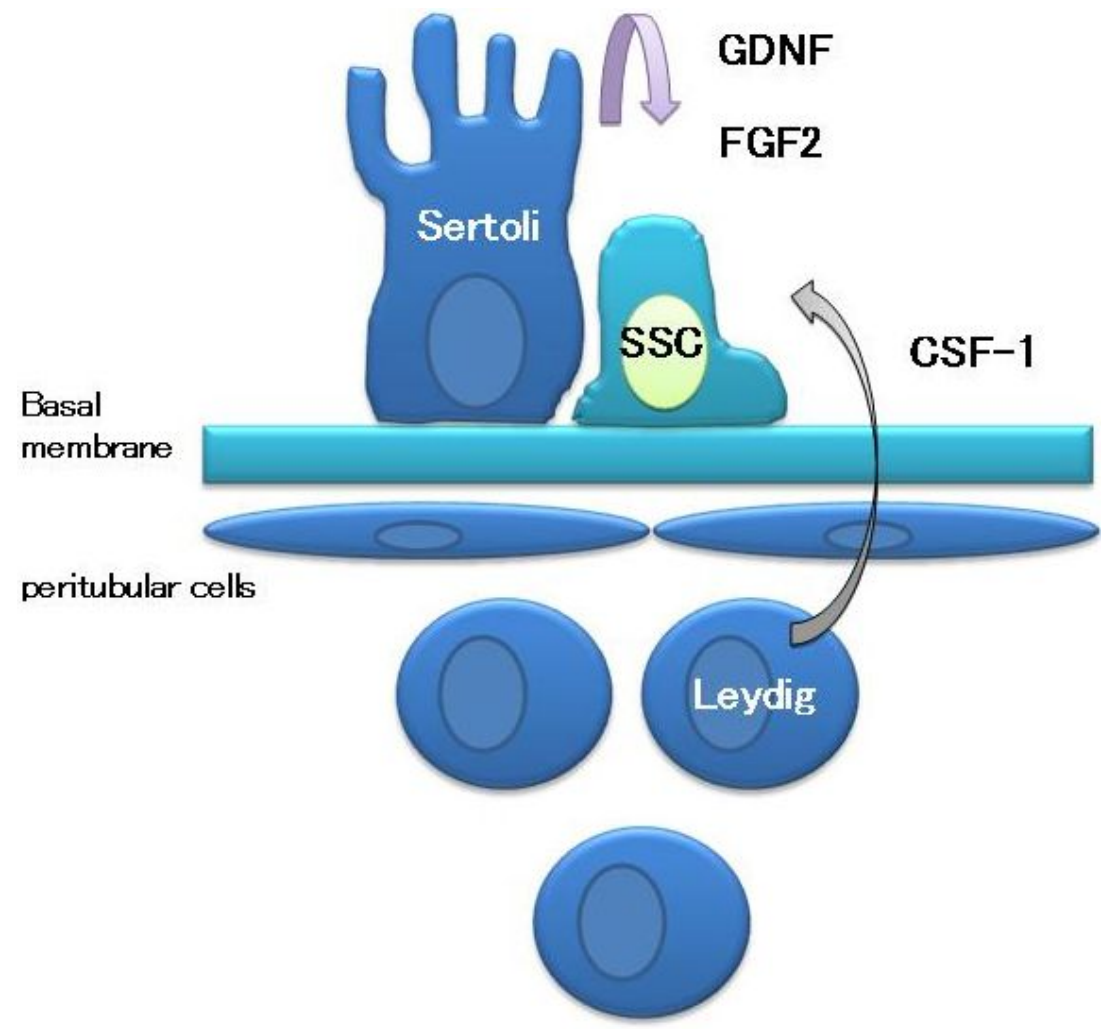

Figure 1. Diagram of the spermatogonial stem cell (SSC) niche showing that extrinsic factors drive SSC maintenance and self-renewal. SSCS and Sertoli cells are attached to the basement membrane. Sertoli cells produce glial cell linederived neurotrophic factor (GDNF) and basic fibroblast growth factor (bFGF). Leydig cells and peritubular cells produce colony-stimulating factor-1 (CSF-1).

for some markers identified in mouse SSCs and other undifferentiated spermatogonia, including GFRA1, UCHL1 (PGP9.5), ZBTB16 (PLZF), and THY1 (CD90) [27,28]. We also have obtained evidence that THY1 is a potential surface marker for human SSCs [29].

Brinster and colleagues proved the existence of mouse SSCs by using unique approaches [30, 31]. These investigators transplanted cells obtained as testicular homogenates expressing the $\mathrm{LacZ}$ gene into the seminiferous tubules of otherwise sterile mice with a Sertoli-cell-only pathology. After three months, the transplanted spermatogonial stem cells had engrafted and colonized the seminiferous tubules. Spermatogenesis was restored.

The clinical implications of this work are enormous. The findings suggest that the isolation, enrichment, and cryopreservation of spermatogonial stem cells prior to chemotherapy or radiation therapy, with later autologous transplantation, may offer the potential for the subsequent restoration of fertility. The development of this technique will be especially important for survivors of childhood cancer. Adult patients can also bank sperm for cryopre- 
servation. However, most couples would prefer a naturally conceived child. Work has progressed in many laboratories to partially enrich the spermatogonial stem cells of species ranging from mice to primates. Today, many urologists bank a testicular biopsy from patients about to undergo chemotherapy, with the expectation that technology will advance rapidly over the next 10 years and allow transplantation in the future.

\section{Pluripotency of human testis-derived ESC-like cells}

Previous studies have demonstrated that neonatal and adult germline stem cells (GSCs) can be self-reprogrammed into ESC-like cells, called germline-derived pluripotent stem cells $[32,33,34,35]$. In addition, Conrad et al. [36] reported that pluripotent cells can be derived from human testis, which those authors called human adult GSCs (haGSCs). Other research groups subsequently claimed that ESC-like cells could be obtained from cultures of human testicular cells $[37,38,39]$. Conrad and colleagues compared the global gene expression profile of hESCs and haGSCs, and concluded that the populations presented a similar gene expression profile, and thus, that the haGSCs were pluripotent. However, Ko et al. claimed that the gene expression profile of haGSCs differed substantially from the pluripotent profile of hESCs, determined by a number of laboratories [40]. For example, the haGSCs did not express NANOG, and had low OCT4 and SOX2 levels, but showed high levels of the fibroblast markers SNA12 and ACTA2 [40]. Ko and colleagues therefore suggested that the haGSCs originated from fibroblast cells, rather than from pluripotent tissue. They concluded that haGSCs were very similar to a human testicular fibroblast cell line (hTFCs) [40]. Conrad and colleagues argued that microarray data sets cannot be compared unless they are processed in parallel in the same experiment, suggesting that the similarity between haGSCs and hTFCs was inconclusive. However, studies on microarray results generated by different laboratories $[41,42,43]$ have shown that findings from microarray analyses are comparable across multiple laboratories [44], particularly when a common platform and set of procedures are used. These findings justify the utility of microarray repositories, such as the GEO database [45], not only as data warehouses but also as resources for comparative and combinatory analyses of microarray data from different laboratories. In conclusion, the global gene expression analysis of haGSCs demonstrated that these cells resembled fibroblast hTFCs more than pluripotent hESCs.

\section{Induced pluripotent stem (iPS) cells}

The year 2006 saw the first description of mouse induced pluripotent stem cells (miPSCs), which were generated by the retrovirus-mediated transduction of four transcription factors (OCT3/4, SOX2, KLF4, and C-MYC) into mouse fibroblasts [46]. Human somatic cells can be reprogrammed to become human iPSCs via the introduction of a small set of genes, either those encoding OCT3/4, SOX2 and KLF4, with or without the addition of C-MYC, or an alternate combination of OCT3/4, SOX2, LIN28, and NANOG [47,48,49,50,51,52,53,54,55]. Human iPSCs (hiPSCs) have remarkable similarity to hESCs in terms of their morphology, in 
vitro characteristics, proliferation rate, gene expression, and ability to differentiate into mesoderm, endoderm, and ectoderm, both in vitro and in vivo, in teratoma assays $[56,57]$.

In our laboratory, we induced iPS cells from adult human testicular tissue by introducing four transcription factors, OCT4, SOX2, KLF4, and C-MYC, using lentiviral vectors [58]. We also generated ES-like cells from 293FT cells by using OCT4, SOX2, NANOG, and LIN28 [59]. Finally, we generated iPS cells derived from the human testicular tissue of individuals with Klinefelter syndrome (KS, also called 47, XXY) [60].

\section{Germline differentiation from ESCs and iPSCs in humans}

Recent studies indicate that mouse $[61,62,63,64,65]$ and human $[66,67][50,68,69,70,71]$ ESCs can differentiate in vitro into oocyte- or sperm-like cells. In particular, Clark et al. first reported the spontaneous differentiation of germ cells in embryoid bodies derived from human ESCs [66]. Male germline cells express specific RNA and protein markers, such as VASA. In 2009, Park et al. demonstrated that PGC-like cells can be differentiated from human iPSCs [50]. Subsequent reports on male germline differentiation from stem cells have used one of three approaches: (1) specific culture conditions, (2) manipulation of gene expression, and (3) purification of germ cells.

Culture conditions supporting differentiation into germline cells. Bucay et al. observed that as hESCs differentiate into putative germline cells, they also produce Sertoli-like support cells [69]. In addition, co-cultures of hESCs and hiPSCs with human fetal gonadal stromal cells [50], mouse Sertoli cells [72], or mouse embryonic fibroblasts [67] resulted in the increased efficiency of germ cell-like differentiation. Co-culture systems are used to mimic a suitable microenvironment for the growing germ cells. For the differentiation of germline-like cells from hESCs and hiPSCs, cytokines and other cell-signaling molecules are often added to the cultures. For example, BMP4 and other BMPs are added to promote PGC-like differentiation from hESCs and hiPSCs [73,74,75]. In addition, retinoic acid has been used to stimulate meiosis [75] [76]. Panula and colleagues reported the differentiation of fetal- and adult-derived iPSCs into germ cells, and showed that $\sim 5 \%$ of human iPSCs differentiated into PGCs following induction with BMPs [77].

Manipulation of gene expression. By manipulating gene expression, researchers can regulate the cell lineage decisions of differentiating pluripotent stem cells. Overexpression of DAZL and VASA promotes PGC formation in differentiating human ESCs and iPSCs [78]. In addition, Kee and colleagues (2009) reported that hESCs differentiate into germline cells that initiate meiosis and progress to form haploid germ cells. These authors indicated that the overexpression of members of the DAZ gene family, DAZ, DAZL, and BOULE, promoted the progression of PGCs to meiosis and the production of haploid cells, a process that is unique to germ cell development [71].

Purification of germline cells. The isolation and purification of germline cells from stem cell cultures (ESCs and iPSCs) can be performed efficiently when specific antibodies for germ cell 
surface markers are available. To purify PGC-like cells from differentiating human ESCs and iPSCs, cell sorting with specific antibodies for SSEA1 [68], SSEA1 and C-KIT [50] [79], or CXCR4 [69] has been effective. In particular, Eguizabal et al. (2011) published a straightforward protocol for germline cell purification that requires only three steps. First, human iPSCs and hESCs are allowed to differentiate for 3 weeks in a monolayer, in the absence of growth cytokines. Second, the cells are cultured for 3 weeks in the presence of retinoic acid. Finally, after these 6 weeks of differentiation, the cells are sorted for a specific combination of surface markers (CD49f++, CD9+, CD90-, and SSEA4-), and the isolated fraction is cultured in the presence of LIF, bFGF, Forskolin, and CYP26 inhibitor for 4 more weeks [76].

\section{Germline differentiation from porcine iPSCs, non-human iPSCs}

Despite their undoubted promise as sources of cells for tissue transplants, many roadblocks remain against using human ESCs clinically. Particularly troubling is the lack of tests for the efficacy of such therapies and the safety of transferring these cells in animals whose anatomy and physiology resemble those of humans better than mouse models do [80] [81] [82] [83] [84]. The pig is a potentially useful model in this regard, because of its similarities to humans in organ size, immunology, and whole animal physiology [85] [86] [87]. It was reported that porcine somatic cells can be reprogrammed to form piPSCs [88]. However, no reports on germline development from piPSCs have been published to date.

\section{Conclusions}

Research on stem cells has shown remarkable progress over the past 5 years. In particular, the development of human iPSCs has opened new avenues into the generation of an in vitro disease model of male infertility. However, improvements are still needed before stem cells can be used clinically. For the treatment and diagnosis of male infertility, future advances may enable spermatids to be differentiated from germline stem cells or iPS cells. In addition, by examining patient-specific iPSCs that are defective in their ability to generate germ cells and comparing their differentiation capacity with that of normal human ESCs and iPSCs, researchers can hope to uncover the nature of male infertility and to design new methods to reverse it.

\section{Acknowledgements}

This study was supported in part by a Grant-in-Aid for Young Scientists (B) of the Japan Society for the Promotion of Science (JSPS) and a Grant of the Strategic Research Foundation Grantaided Project for Private schools at Heisei 23th from Ministry of Education, Culture, Sports, Science and Technology of Japan, 2011-2015. 


\section{Author details}

Hideyuki Kobayashi", Koichi Nagao and Koichi Nakajima

*Address all correspondence to: hideyukk@med.toho-u.ac.jp

Department of Urology, Toho University School of Medicine, Tokyo, Japan

\section{References}

[1] Spira, A. Epidemiology of human reproduction. Hum Reprod (1986). , 1, 111-5.

[2] MacLeod JHuman male infertility. Obstet Gynecol Surv (1971). , 26, 335-51.

[3] Mosher, W. D. Reproductive impairments in the United States, 1965-1982. Demography (1985). , 22, 415-30.

[4] Simmons, F. A. Human infertility. N Engl J Med (1956). contd., 255, 1140-6.

[5] Lue, Y, Erkkila, K, Liu, P. Y, Ma, K, Wang, C, Hikim, A. S, et al. Fate of bone marrow stem cells transplanted into the testis: potential implication for men with testicular failure. Am J Pathol (2007). , 170, 899-908.

[6] Nieschlag, E, Simoni, M, Gromoll, J, \& Weinbauer, G. F. Role of FSH in the regulation of spermatogenesis: clinical aspects. Clin Endocrinol (Oxf) (1999). , 51, 139-46.

[7] Allan, C. M, Couse, J. F, Simanainen, U, Spaliviero, J, Jimenez, M, Rodriguez, K, et al. Estradiol induction of spermatogenesis is mediated via an estrogen receptor-\{alpha\} mechanism involving neuroendocrine activation of follicle-stimulating hormone secretion. Endocrinology (2010). , 151, 2800-10.

[8] Schlegel, P. N. Nonobstructive azoospermia: a revolutionary surgical approach and results. Semin Reprod Med (2009). , 27, 165-70.

[9] Kuwana, T, \& Fujimoto, T. Active locomotion of human primordial germ cells in vitro. Anat Rec (1983). , 205, 21-6.

[10] Shamblott, M. J, Axelman, J, Wang, S, Bugg, E. M, Littlefield, J. W, Donovan, P. J, et al. Derivation of pluripotent stem cells from cultured human primordial germ cells. Proc Natl Acad Sci U S A (1998). , 95, 13726-31.

[11] Perrett, R. M, Turnpenny, L, Eckert, J. J, Shea, O, Sonne, M, \& Cameron, S. B. IT et al. The early human germ cell lineage does not express SOX2 during in vivo development or upon in vitro culture. Biol Reprod (2008). , 78, 852-8. 
[12] De Jong, J, Stoop, H, Gillis, A. J, \& Van Gurp, R. J. van de Geijn GJ, Boer M et al. Differential expression of SOX17 and SOX2 in germ cells and stem cells has biological and clinical implications. J Pathol (2008). , 215, 21-30.

[13] Kerr, C. L, Hill, C. M, Blumenthal, P. D, \& Gearhart, J. D. Expression of pluripotent stem cell markers in the human fetal testis. Stem Cells (2008). , 26, 412-21.

[14] Kerr, C. L, Hill, C. M, Blumenthal, P. D, \& Gearhart, J. D. Expression of pluripotent stem cell markers in the human fetal ovary. Hum Reprod (2008). , 23, 589-99.

[15] De Rooij, D. G, \& Russell, L. D. All you wanted to know about spermatogonia but were afraid to ask. J Androl (2000). , 21, 776-98.

[16] Meng, X, Lindahl, M, Hyvonen, M. E, Parvinen, M, De Rooij, D. G, Hess, M. W, et al. Regulation of cell fate decision of undifferentiated spermatogonia by GDNF. Science (2000). , 287, 1489-93.

[17] Kanatsu-shinohara, M, Ogonuki, N, Inoue, K, Miki, H, Ogura, A, Toyokuni, S, et al. Long-term proliferation in culture and germline transmission of mouse male germline stem cells. Biol Reprod (2003). , 69, 612-6.

[18] Kubota, H, Avarbock, M. R, \& Brinster, R. L. Growth factors essential for self-renewal and expansion of mouse spermatogonial stem cells. Proc Natl Acad Sci U S A (2004). , 101, 16489-94.

[19] Oatley, J. M, Oatley, M. J, Avarbock, M. R, Tobias, J. W, \& Brinster, R. L. Colony stimulating factor 1 is an extrinsic stimulator of mouse spermatogonial stem cell self-renewal. Development (2009). , 136, 1191-9.

[20] Huckins, C. The spermatogonial stem cell population in adult rats. 3. Evidence for a long-cycling population. Cell Tissue Kinet (1971). , 4, 335-49.

[21] Huckins, C. The spermatogonial stem cell population in adult rats. II. A radioautographic analysis of their cell cycle properties. Cell Tissue Kinet (1971). , 4, 313-34.

[22] Huckins, C. The spermatogonial stem cell population in adult rats. I. Their morphology, proliferation and maturation. Anat Rec (1971). , 169, 533-57.

[23] Clermont, Y. The cycle of the seminiferous epithelium in man. Am J Anat (1963). , $112,35-51$.

[24] Clermont, Y. Renewal of spermatogonia in man. Am J Anat (1966). , 118, 509-24.

[25] Clermont, Y. Spermatogenesis in man. A study of the spermatogonial population. Fertil Steril (1966). , 17, 705-21.

[26] Clermont, Y. Kinetics of spermatogenesis in mammals: seminiferous epithelium cycle and spermatogonial renewal. Physiol Rev (1972). , 52, 198-236.

[27] He, Z, Kokkinaki, M, Jiang, J, Dobrinski, I, \& Dym, M. Isolation, characterization, and culture of human spermatogonia. Biol Reprod (2010). , 82, 363-72. 
[28] Dym, M, Kokkinaki, M, \& He, Z. Spermatogonial stem cells: mouse and human comparisons. Birth Defects Res C Embryo Today (2009). , 87, 27-34.

[29] Kobayashi, H, Nagao, K, Nakajima, K, Miura, K, \& Ishii, N. Thy-1 $1^{+}$cells isolated from adult human testicular tissues express human embryonic stem cell genes OCT3/4 and NANOG and may include spermatogonial stem cells. Reprod Med Biol (2009).

[30] Brinster, R. L, \& Avarbock, M. R. Germline transmission of donor haplotype following spermatogonial transplantation. Proc Natl Acad Sci U S A (1994). , 91, 11303-7.

[31] Brinster, R. L, \& Zimmermann, J. W. Spermatogenesis following male germ-cell transplantation. Proc Natl Acad Sci U S A (1994). , 91, 11298-302.

[32] Ko, K, Tapia, N, Wu, G, Kim, J. B, Bravo, M. J, Sasse, P, et al. Induction of pluripotency in adult unipotent germline stem cells. Cell Stem Cell (2009). , 5, 87-96.

[33] Kanatsu-shinohara, M, Inoue, K, Lee, J, Yoshimoto, M, Ogonuki, N, Miki, H, et al. Generation of pluripotent stem cells from neonatal mouse testis. Cell (2004). , 119, 1001-12.

[34] Seandel, M, James, D, Shmelkov, S. V, Falciatori, I, Kim, J, Chavala, S, et al. Generation of functional multipotent adult stem cells from GPR125+ germline progenitors. Nature (2007). , 449, 346-50.

[35] Kanatsu-shinohara, M, Lee, J, Inoue, K, Ogonuki, N, Miki, H, Toyokuni, S, et al. Pluripotency of a single spermatogonial stem cell in mice. Biol Reprod (2008). , 78, 681-7.

[36] Conrad, S, Renninger, M, Hennenlotter, J, Wiesner, T, Just, L, Bonin, M, et al. Generation of pluripotent stem cells from adult human testis. Nature (2008). , 456, 344-9.

[37] Golestaneh, N, Kokkinaki, M, Pant, D, Jiang, J, Destefano, D, Fernandez-bueno, C, et al. Pluripotent stem cells derived from adult human testes. Stem Cells Dev (2009). , $18,1115-26$.

[38] Kossack, N, Meneses, J, Shefi, S, Nguyen, H. N, Chavez, S, Nicholas, C, et al. Isolation and characterization of pluripotent human spermatogonial stem cell-derived cells. Stem Cells (2009). , 27, 138-49.

[39] Mizrak, S. C, Chikhovskaya, J. V, Sadri-ardekani, H, Van Daalen, S, Korver, C. M, Hovingh, S. E, et al. Embryonic stem cell-like cells derived from adult human testis. Hum Reprod (2010). , 25, 158-67.

[40] Ko, K, Arauzo-bravo, M. J, Tapia, N, Kim, J, Lin, Q, Bernemann, C, et al. Human adult germline stem cells in question. Nature (2010). E1; discussion E3.

[41] Bammler, T, Beyer, R. P, Bhattacharya, S, Boorman, G. A, Boyles, A, Bradford, B. U, et al. Standardizing global gene expression analysis between laboratories and across platforms. Nat Methods (2005). , 2, 351-6. 
[42] Larkin, J. E, Frank, B. C, Gavras, H, Sultana, R, \& Quackenbush, J. Independence and reproducibility across microarray platforms. Nat Methods (2005). , 2, 337-44.

[43] Irizarry, R. A, Warren, D, Spencer, F, Kim, I. F, Biswal, S, Frank, B. C, et al. Multiplelaboratory comparison of microarray platforms. Nat Methods (2005). , 2, 345-50.

[44] Sherlock, G. Of fish and chips. Nat Methods (2005). , 2, 329-30.

[45] Edgar, R, Domrachev, M, \& Lash, A. E. Gene Expression Omnibus: NCBI gene expression and hybridization array data repository. Nucleic Acids Res (2002). , 30, 207-10.

[46] Takahashi, K, \& Yamanaka, S. Induction of pluripotent stem cells from mouse embryonic and adult fibroblast cultures by defined factors. Cell (2006). , 126, 663-76.

[47] Okita, K, Ichisaka, T, \& Yamanaka, S. Generation of germline-competent induced pluripotent stem cells. Nature (2007). , 448, 313-7.

[48] Yu, J, Vodyanik, M. A, Smuga-otto, K, Antosiewicz-bourget, J, Frane, J. L, Tian, S, et al. Induced pluripotent stem cell lines derived from human somatic cells. Science (2007). , 318, 1917-20.

[49] Woltjen, K, Michael, I. P, Mohseni, P, Desai, R, Mileikovsky, M, Hamalainen, R, et al. piggyBac transposition reprograms fibroblasts to induced pluripotent stem cells. Nature (2009). , 458, 766-70.

[50] Park, T. S, Galic, Z, Conway, A. E, Lindgren, A, Van Handel, B. J, Magnusson, M, et al. Derivation of primordial germ cells from human embryonic and induced pluripotent stem cells is significantly improved by coculture with human fetal gonadal cells. Stem Cells (2009). , 27, 783-95.

[51] Zou, J, Maeder, M. L, Mali, P, Pruett-miller, S. M, Thibodeau-beganny, S, Chou, B. K, et al. Gene targeting of a disease-related gene in human induced pluripotent stem and embryonic stem cells. Cell Stem Cell (2009). , 5, 97-110.

[52] Nakagawa, M, Koyanagi, M, Tanabe, K, Takahashi, K, Ichisaka, T, Aoi, T, et al. Generation of induced pluripotent stem cells without Myc from mouse and human fibroblasts. Nat Biotechnol (2008). , 26, 101-6.

[53] Takahashi, K, Okita, K, Nakagawa, M, \& Yamanaka, S. Induction of pluripotent stem cells from fibroblast cultures. Nat Protoc (2007). , 2, 3081-9.

[54] Liu, H, Zhu, F, Yong, J, Zhang, P, Hou, P, Li, H, et al. Generation of induced pluripotent stem cells from adult rhesus monkey fibroblasts. Cell Stem Cell (2008). , 3, 587-90.

[55] Takahashi, K, Tanabe, K, Ohnuki, M, Narita, M, Ichisaka, T, Tomoda, K, et al. Induction of pluripotent stem cells from adult human fibroblasts by defined factors. Cell (2007). , 131, 861-72. 
[56] Yamanaka, S. Strategies and new developments in the generation of patient-specific pluripotent stem cells. Cell Stem Cell (2007). , 1, 39-49.

[57] Yamanaka, S. Pluripotency and nuclear reprogramming. Philos Trans R Soc Lond B Biol Sci (2008). , 363, 2079-87.

[58] Kobayashi, H, Nakajima, K, Oka, Y, Tai, T, Nagao, K, \& Ishii, N. Reprogramming of adult human testicular cells by our transcription factors (OCT4, SOX2, KLF4, and CMYC). Reprod Med Biol (2011). , 10, 105-112.

[59] Oka, Y, Nakajima, K, Nagao, K, Miura, K, Ishii, N, \& Kobayashi, H. FT cells transduced with four transcription actors (OCT4, SOX2, NANOG, and LIN28) generate aberrant ES-like cells. J. Stem cell and Regenerative Medicine (2010). , 3, 149-156.

[60] Kobayashi, H. Pluripotent stem cells induced from testicular tissue with Klinefelter syndrome (47, XXY) by four ranscription factors (OCT4, SOX2, KLF4, and C-MYC). Methodological Advances in the Culture, Manipulation and Utilization of Embryonic Stem Cells for Basic and Practical Applications (2011). , 295-306.

[61] Hubner, K, Fuhrmann, G, Christenson, L. K, Kehler, J, Reinbold, R, De La Fuente, R, et al. Derivation of oocytes from mouse embryonic stem cells. Science (2003). , 300, 1251-6.

[62] Toyooka, Y, Tsunekawa, N, Akasu, R, \& Noce, T. Embryonic stem cells can form germ cells in vitro. Proc Natl Acad Sci U S A (2003). , 100, 11457-62.

[63] Geijsen, N, Horoschak, M, Kim, K, Gribnau, J, Eggan, K, \& Daley, G. Q. Derivation of embryonic germ cells and male gametes from embryonic stem cells. Nature (2004). , $427,148-54$.

[64] Qing, T, Shi, Y, Qin, H, Ye, X, Wei, W, Liu, H, et al. Induction of oocyte-like cells from mouse embryonic stem cells by co-culture with ovarian granulosa cells. Differentiation (2007). , 75, 902-11.

[65] Nagano, M. C. In vitro gamete derivation from pluripotent stem cells: progress and perspective. Biol Reprod (2007). , 76, 546-51.

[66] Clark, A. T, Bodnar, M. S, Fox, M, Rodriquez, R. T, Abeyta, M. J, Firpo, M. T, et al. Spontaneous differentiation of germ cells from human embryonic stem cells in vitro. Hum Mol Genet (2004). , 13, 727-39.

[67] West, F. D, Machacek, D. W, Boyd, N. L, Pandiyan, K, Robbins, K. R, \& Stice, S. L. Enrichment and differentiation of human germ-like cells mediated by feeder cells and basic fibroblast growth factor signaling. Stem Cells (2008). , 26, 2768-76.

[68] Tilgner, K, Atkinson, S. P, Golebiewska, A, Stojkovic, M, Lako, M, \& Armstrong, L. Isolation of primordial germ cells from differentiating human embryonic stem cells. Stem Cells (2008). , 26, 3075-85. 
[69] Bucay, N, Yebra, M, Cirulli, V, Afrikanova, I, Kaido, T, Hayek, A, et al. A novel approach for the derivation of putative primordial germ cells and sertoli cells from human embryonic stem cells. Stem Cells (2009). , 27, 68-77.

[70] Tilgner, K, Atkinson, S. P, Yung, S, Golebiewska, A, Stojkovic, M, Moreno, R, et al. Expression of GFP under the control of the RNA helicase VASA permits fluorescence-activated cell sorting isolation of human primordial germ cells. Stem Cells (2010). , 28, 84-92.

[71] Kee, K, Angeles, V. T, Flores, M, \& Nguyen, H. N. Reijo Pera RA. Human DAZL, DAZ and BOULE genes modulate primordial germ-cell and haploid gamete formation. Nature (2009). , 462, 222-5.

[72] Geens, M, \& Sermon, K. D. Van de Velde H, Tournaye H. Sertoli cell-conditioned medium induces germ cell differentiation in human embryonic stem cells. J Assist Reprod Genet (2011). , 28, 471-80.

[73] West, F. D, Roche-rios, M. I, Abraham, S, Rao, R. R, Natrajan, M. S, Bacanamwo, M, et al. KIT ligand and bone morphogenetic protein signaling enhances human embryonic stem cell to germ-like cell differentiation. Hum Reprod (2010). , 25, 168-78.

[74] Kee, K, Gonsalves, J. M, Clark, A. T, \& Pera, R. A. Bone morphogenetic proteins induce germ cell differentiation from human embryonic stem cells. Stem Cells Dev (2006). , 15, 831-7.

[75] Richards, M, Fong, C. Y, \& Bongso, A. Comparative evaluation of different in vitro systems that stimulate germ cell differentiation in human embryonic stem cells. Fertil Steril (2010). , 93, 986-94.

[76] Eguizabal, C, Montserrat, N, Vassena, R, Barragan, M, Garreta, E, Garcia-quevedo, L, et al. Complete meiosis from human induced pluripotent stem cells. Stem Cells (2011). , 29, 1186-95.

[77] Panula, S, Medrano, J. V, Kee, K, Bergstrom, R, Nguyen, H. N, Byers, B, et al. Human germ cell differentiation from fetal- and adult-derived induced pluripotent stem cells. Hum Mol Genet (2011). , 20, 752-62.

[78] Medrano, J. V, Ramathal, C, Nguyen, H. N, \& Simon, C. Reijo Pera RA. Divergent RNA-binding proteins, DAZL and VASA, induce meiotic progression in human germ cells derived in vitro. Stem Cells (2012). , 30, 441-51.

[79] Aflatoonian, B, Ruban, L, Jones, M, Aflatoonian, R, Fazeli, A, \& Moore, H. D. In vitro post-meiotic germ cell development from human embryonic stem cells. Hum Reprod (2009). , 24, 3150-9.

[80] Vackova, I, Ungrova, A, \& Lopes, F. Putative embryonic stem cell lines from pig embryos. J Reprod Dev (2007). , 53, 1137-49. 
[81] Keefer, C. L, Pant, D, Blomberg, L, \& Talbot, N. C. Challenges and prospects for the establishment of embryonic stem cell lines of domesticated ungulates. Anim Reprod Sci (2007). , 98, 147-68.

[82] Brevini, T. A, Antonini, S, Cillo, F, Crestan, M, \& Gandolfi, F. Porcine embryonic stem cells: Facts, challenges and hopes. Theriogenology (2007). Suppl 1:S, 206-13.

[83] Talbot, N. C. Blomberg Le A. The pursuit of ES cell lines of domesticated ungulates. Stem Cell Rev (2008). , 4, 235-54.

[84] Hall, V. Porcine embryonic stem cells: a possible source for cell replacement therapy. Stem Cell Rev (2008). , 4, 275-82.

[85] Prather, R. S, Hawley, R. J, Carter, D. B, Lai, L, \& Greenstein, J. L. Transgenic swine for biomedicine and agriculture. Theriogenology (2003). , 59, 115-23.

[86] Brandl, U, Michel, S, Erhardt, M, Brenner, P, Burdorf, L, Jockle, H, et al. Transgenic animals in experimental xenotransplantation models: orthotopic heart transplantation in the pig-to-baboon model. Transplant Proc (2007). , 39, 577-8.

[87] Piedrahita, J. A, \& Mir, B. Cloning and transgenesis in mammals: implications for xenotransplantation. Am J Transplant (2004). Suppl , 6, 43-50.

[88] Ezashi, T, Telugu, B. P, Alexenko, A. P, Sachdev, S, Sinha, S, \& Roberts, R. M. Derivation of induced pluripotent stem cells from pig somatic cells. Proc Natl Acad Sci U S A (2009). , 106, 10993-8. 